\title{
EFFECT OF CULTURE PARAMETERS ON PROTEASE AND CELLULASE PRODUCTION BY TWO BACTERIAL STRAINS, Corynebacterium alkanolyticum ATH3 AND Bacillus licheniformis CBH7 ISOLATED FROM FISH GUT
}

\author{
GOUTAM BANERJEE ${ }^{1,2}$, ANKITA NANDI ${ }^{1}$ and ARUN KUMAR RAY ${ }^{1, *}$ \\ ${ }^{1}$ Department of Zoology, Visva-Bharati University, Santiniketan 731235, India \\ ${ }^{2}$ Department of Biochemistry, University of Calcutta, Kolkata 700019, India
}

Received 7 August 2016/Accepted 22 July 2017

\begin{abstract}
Microbial protease and cellulase are in high demand by different industries due to their minimal cost and availability. This study was aimed to maximize the production of protease and cellulase using two bacteria, Corynebacterium alkanolyticum ATH3 and Bacillus licheniformis $\mathrm{CBH7}$, isolated from fish gut. This study demonstrated the effect of different culture parameters in protease and cellulase production using two different bacterial strains. Results of this study clearly indicated the importance of different parameters such as moisture content, $\mathrm{pH}$, incubation temperature, incubation period, inoculum size, carbon sources and nitrogen sources in enzyme production. The most critical parameters affecting the enzymes production were $\mathrm{pH}$, temperature, carbon and nitrogen sources. Further investigations are required to enhance the enzymes production using genetic engineering.
\end{abstract}

Keywords: Bacterial strains, culture parameters, product maximization, protease and cellulase

\section{INTRODUCTION}

Protease catalyzes the hydrolysis of protein and cellulose forming amino acids, while cellulase catalyzes glucose (Ray et al. 2012a). Protease and cellulase are biotechnologically very important and mainly isolated from different living organisms such as plants, bacteria and fungi (Saddler 1993; Gupta et al. 2002; Banerjee et al. 2015b). Gut bacteria are proven to produce various substances such as vitamin $K$, riboflavin, and various enzymes (e.g. protease, amylase, cellulase, lipase, phytase) (Ray et al. 2012a). Proteases isolated from microbial source are preferred over the enzymes isolated from plant and animal sources because they possess all the characteristics required for their biotechnological application (Rao et al. 1998; Beg \& Gupta 2003). Proteases constitute $50-65 \%$ of the global industrial enzymes market (Banerjee et al. 2015b). Proteases from microbial sources are widely used in different industries such as food, textile and

* Corresponding author: aray51@yahoo.com beverages (Pastor et al. 2001). Proteases are useful for preparing high quality functional feeds through bioconversion of low-cost feed materials (Esakkiraj et al. 2007). Among several bacterial strains, genus Bacillus is considered to be the most important commercial enzyme producers (Ray et al.2012a; Banerjee \& Ray 2016).

Cellulose, a polymer of glucose, is the primary structural component of most plant cell walls. Although this polysaccharide is the most common carbohydrate on earth, relatively few animals are able to utilize this resource efficiently (Goodenough \& Goodenough 1993; He et al. 2015). Utilization of cellulose as a nutrient source requires enzymes that cleave beta-1, 4 glycosidic bonds between constituent sugars. The enzyme referred to as cellulases, are required to split beta1, 4 glycosidic bonds in the polymer to release glucose units (Barr et al. 1996). Although a large number of microorganisms are capable of degrading cellulose, only a few of these microorganisms produce significant quantities of extracellular enzymes capable of completely hydrolyzing crystalline cellulose in vitro. Fungi are 
the main cellulase-producing microorganisms, though a few bacteria and actinomycetes are also recently reported to be good producer of cellulase (Ray et al. 2012a; Lugani et al. 2015; Banerjee \& Ray 2016).

Microbial enzymes have the advantage of large scale production using established fermentation techniques. A successful fermentation process requires favorable environmental and nutritional conditions for the microorganisms (Ray et al. 2007). Information on the optimum conditions for protease and cellulase production using fish gut bacteria is limited (Esakkiraj et al. 2007; Ray et al. 2007, 2012b). This study was aimed to optimize the environmental and nutritional parameters to enhance protease and cellulase production using two bacterial strains, Corynebacterium alkanolyticum ATH3 and Bacillus licheniformis $\mathrm{CBH} 7$, isolated from the gut of climbing perch, Anabas testudineus and walking catfish, Clarias batrachus, respectively.

\section{MATERIALS AND METHODS}

\section{Bacterial Strains and Culture Medium}

Two bacterial strains Corynebacterium alkanolyticum ATH3 (GenBank accession no. JX656749) and Bacillus licheniformis $\mathrm{CBH} 7$ (GenBank accession no. HQ005269) were isolated from the gut of two species of Indian airbreathing fish, i.e. climbing perch, Anabas testudineus and walking catfish, Clarias batrachus, respectively (Banerjee \& Ray 2013; Banerjee et al. 2015a). Both isolates were cultured in Tryptone Soya Agar broth for 24 hours at $30 \mathrm{oC}$ to increase the viable count. The bacterial culture medium was prepared according to Ray et al. (2012b).

\section{Enzyme Assay}

Extracellular protease activity was assayed following the method of Walter (1984). The amount of tyrosine released in the assay medium was measured at $273 \mathrm{~nm}$. Cellulase activity was estimated according to the method of Denison and Kohen (1977). The production of reducing sugar (glucose) from CMC substrate through cellulolytic activity was measured at $540 \mathrm{~nm}$. One unit of specific activity is defined as amount of product released per milligram protein per milliliter enzyme per minute. Protein concentration was determined according to Lowry et al. (1951) using bovine serum albumin as a standard.

\section{Effect of Different Physical Parameters on Enzyme Production}

\section{Moisture content maximization}

In order to determine the optimum moisture content, bacteria were cultured in protease (peptone-gelatin) and cellulase media (carboxymethylcellulose), which were prepared by moistening the media with basal salt (elaborate basal salt) solution. Moisture content of the fermentation medium ranged from 5 to $75 \%$.

\section{Effect of $p H$ of the medium}

Optimization of suitable $\mathrm{pH}$ for enzymes production was determined by culturing the bacterial strains in Tryptone Soya Agar broth at different $\mathrm{pH}$ ranging from 5.0 - 10.0.

\section{Incubation temperature maximization}

Optimum temperature of incubation for protease and cellulase production was determined by culturing the bacterial strains at increasing temperature ranging from 20 to $50{ }^{\circ} \mathrm{C}$ with $10{ }^{\circ} \mathrm{C}$ intervals.

\section{Incubation period maximization}

Incubation period is one of the most important parameter in fermentation process. To determine the optimum incubation period, enzymes activity was measured up to 120 hours at an interval of 24 hours.

\section{Effect of inoculum size}

For this purpose, fermentation media were seeded with $1 \%, 2 \%, 3 \%, 4 \%, 5 \%$ and $6 \%$ seed culture in Tryptone Soya Agar broth.

\section{Effect of different carbon sources}

In order to optimize the suitable carbon source for enzyme production, fermentation media were prepared with different carbon sources such as glucose, maltose, sucrose, lactose, arabinose, fructose and starch. These alternative carbon sources at $0.2 \%$ level were used to replace the original carbon source in the media.

\section{Effect of different nitrogen sources}

To optimize the appropriate nitrogen source, the fermentation media were supplemented with both organic (arginine, L-asparagine, tryoptone, beef extract, tyrosine, gelatin) and inorganic 
(ammonium chloride, ammonium sulphate, sodium nitrate and potassium nitrate) nitrogen sources at $0.2 \%$ level replacing the original nitrogen source in the media.

\section{Statistical Analysis}

The analysis of variance for different values was carried out in Microsoft Excel 2007. One way ANOVA followed by Duncan's Multiple Range Test (Duncan 1955) was conducted at significance level of $p<0.05$.

\section{RESULTS AND DISCUSSION}

Protease and cellulase production using the two bacterial strains at different moisture content $(5-75 \%)$ are tabulated in Table 1.

Protease production using the two bacterial strains was the highest at $10 \%$ moisture content (3.79 $0.155 \mathrm{U}$ in Corynebacterium alkanolyticum ATH3 and 2.16 $\pm 0.132 \mathrm{U}$ in Bacillus licheniformis $\mathrm{CBH7}$ ). Maximum cellulase activity was recorded at $15 \%$ moisture content $(8.34 \pm 0.144 \mathrm{U}$ in $C$. alkanolyticum ATH3 and $6.17 \pm 0.115 \mathrm{U}$ in $B$. licheniformis $\mathrm{CBH7}$ ). Medium maximization was the first and foremost step to enhance enzymes production in laboratory experiments and in fermentation industries. Each and every element should be in a proper amount to fulfill the metabolic process requirements to supply sufficient energy for maximum biomass production (Ray et al. 2012b). Cellulase production reached the maximum level using two bacterial strains Bacillus subtilis and Bacillus circulans at 10\% moisture content (Ray et al. 2007). Protease production reached the optimum level using Bacillus cereus AT at 120\% moisture content (Vijayaraghavan et al. 2014). Moisture content was a crucial factor for producing bacterial extracellular enzyme, because water was required for growth, metabolic activities and biochemical process. Thus, optimum moisture content was required during fermentation process.

$\mathrm{pH}$ of the culture medium was another important factor controlling enzyme production and activity. In the present study, protease production exhibited by $C$. alkanolyticum ATH3 was maximum at $\mathrm{pH} 7.5(3.81 \pm 0.096 \mathrm{U})$, whereas B. licheniformis $\mathrm{CBH} 7$ showed the highest production at $\mathrm{pH} 8.0(2.22 \pm 0.204 \mathrm{U}$ (Table 2$)$.

On the other hand, cellulase production exhibited by these two bacterial strains was recorded to be the highest at $\mathrm{pH} 7.5(8.41 \pm 0.83 \mathrm{U}$ in C. alkeanolyticum ATH3 and $6.27 \pm 0.216 \mathrm{U}$ in $B$. licheniformis $\mathrm{CBH} 7$, Table 2) and thereafter declined rapidly. Cellulase production using Bacillus subtilis CY5 isolated from the gastrointestinal (GI) tracts of common carp, Cyprinus carpio and using B. circulans TP3 isolated from the GI tracts of tilapia, Oreochromis

Table 1 Effect of moisture content on enzyme production

\begin{tabular}{|c|c|c|c|c|}
\hline \multirow{2}{*}{$\begin{array}{l}\text { Moisture } \\
\text { content } \\
(\%)\end{array}$} & \multicolumn{2}{|c|}{ Specific activity of protease $\left(\mathrm{U}^{1}\right)$} & \multicolumn{2}{|c|}{ Specific activity of cellulase $\left(\mathrm{U}^{2}\right)$} \\
\hline & ATH3 & $\mathrm{CBH} 7$ & ATH3 & $\mathrm{CBH} 7$ \\
\hline 5 & $2.79 \pm 0.110^{\mathrm{b}}$ & $1.24 \pm 0.045^{\mathrm{c}}$ & $6.91 \pm 0.183^{c}$ & $4.18 \pm 0.183^{d}$ \\
\hline 10 & $3.79 \pm 0.155^{\mathrm{a}}$ & $2.16 \pm 0.132^{a}$ & $7.56 \pm 0.266^{\mathrm{b}}$ & $5.13 \pm 0.098^{b}$ \\
\hline 15 & $2.63 \pm 0.098^{c}$ & $1.71 \pm 0.055^{\mathrm{b}}$ & $8.34 \pm 0.144^{a}$ & $6.17 \pm 0.115^{a}$ \\
\hline 20 & $1.22 \pm 0.045^{\mathrm{d}}$ & $0.63 \pm 0.08^{\mathrm{d}}$ & $4.25 \pm 0.158^{\mathrm{d}}$ & $4.69 \pm 0.238^{c}$ \\
\hline 25 & $0.71 \pm 0.051^{\mathrm{e}}$ & $0.58 \pm 0.043^{\mathrm{d}}$ & $2.45 \pm 0.062^{\mathrm{e}}$ & $4.31 \pm 0.091^{\mathrm{d}}$ \\
\hline 30 & $0.42 \pm 0.06^{\mathrm{f}}$ & $0.49 \pm 0.034^{\mathrm{e}}$ & $2.29 \pm 0.034^{\mathrm{e}}$ & $3.45 \pm 0.111^{\mathrm{f}}$ \\
\hline 50 & $0.33 \pm 0.036^{\mathrm{f}}$ & $0.66 \pm 0.036^{\mathrm{d}}$ & $2.04 \pm 0.055^{\mathrm{f}}$ & $3.88 \pm 0.135^{\mathrm{e}}$ \\
\hline 75 & $0.29 \pm 0.018 \mathrm{~g}$ & $0.42 \pm 0.062^{\mathrm{e}}$ & $1.38 \pm 0.045 \mathrm{~g}$ & $2.77 \pm 0.078 \mathrm{~g}$ \\
\hline
\end{tabular}

Note: Data are presented as mean \pm SEM. $n=3$ replications.

Numbers followed by the same letter did not differ significantly at $p<0.05$.

$\mathrm{U}^{1}=\mu \mathrm{g}$ of tyrosine liberated $/ \mathrm{mg}$ protein/minute.

$\mathrm{U}^{2}=\mu \mathrm{g}$ of glucose liberated $/ \mathrm{mg}$ protein/minute. 
Table 2 Effect of $\mathrm{pH}$ on protease and celluase production

\begin{tabular}{|c|c|c|c|c|}
\hline \multirow[t]{2}{*}{$\mathrm{pH}$} & \multicolumn{2}{|c|}{ Specific activity of protease $\left(\mathrm{U}^{1}\right)$} & \multicolumn{2}{|c|}{ Specific activity of cellulase $\left(\mathrm{U}^{2}\right)$} \\
\hline & ATH3 & $\mathrm{CBH} 7$ & ATH3 & $\mathrm{CBH} 7$ \\
\hline 5.0 & $0.49 \pm 0.055^{\mathrm{f}}$ & $0.28 \pm 0.052^{\mathrm{f}}$ & $2.09 \pm 0.075^{\mathrm{f}}$ & $2.39 \pm 0.249 \mathrm{e}$ \\
\hline 5.5 & $0.58 \pm 0.043^{\mathrm{f}}$ & $0.71 \pm 0.07 \mathrm{e}$ & $3.82 \pm 0.17 \mathrm{e}$ & $2.95 \pm 0.301^{d}$ \\
\hline 6.0 & $1.74 \pm 0.13^{\mathrm{d}}$ & $1.13 \pm 0.052^{\mathrm{d}}$ & $4.90 \pm 0.262^{\mathrm{d}}$ & $3.48 \pm 0.153^{\mathrm{d}}$ \\
\hline 6.5 & $2.78 \pm 0.193^{c}$ & $1.56 \pm 0.085^{c}$ & $5.77 \pm 0.145^{c}$ & $4.16 \pm 0.202^{c}$ \\
\hline 7.0 & $3.45 \pm 0.16^{\mathrm{b}}$ & $1.73 \pm 0.088^{\mathrm{b}}$ & $7.55 \pm 0.124^{\mathrm{b}}$ & $5.20 \pm 0.215^{b}$ \\
\hline 7.5 & $3.81 \pm 0.096^{\mathrm{a}}$ & $1.94 \pm 0.134^{\mathrm{b}}$ & $8.41 \pm 0.83{ }^{a}$ & $6.27 \pm 0.216^{a}$ \\
\hline 8.0 & $1.61 \pm 0.052^{\mathrm{d}}$ & $2.22 \pm 0.204^{\mathrm{a}}$ & $4.13 \pm 0.410^{\mathrm{e}}$ & $6.09 \pm 0.705^{a}$ \\
\hline 8.5 & $0.86 \pm 0.021^{\mathrm{e}}$ & $1.77 \pm 0.160^{\mathrm{b}}$ & $2.68 \pm 0.461^{\mathrm{f}}$ & $5.10 \pm 0.306^{\mathrm{b}}$ \\
\hline 9.0 & $0.31 \pm 0.01^{\mathrm{f}}$ & $0.95 \pm 0.052^{\mathrm{d}}$ & $1.43 \pm 0.104 \mathrm{~g}$ & $4.49 \pm 0.514^{c}$ \\
\hline
\end{tabular}

Note: Data are presented as mean \pm SEM. $\mathrm{n}=3$ replications.

Numbers followed by the same letter did not differ significantly at $p<0.05$.

$\mathrm{U}^{1}=\mu \mathrm{g}$ of tyrosine liberated/mg protein/minute.

$\mathrm{U}^{2}=\mu \mathrm{g}$ of glucose liberated $/ \mathrm{mg}$ protein $/$ minute.

mossambicus was higher in optimum $\mathrm{pH}$ range of 7.0 to 7.5 (Ray et al. 2007). Protease activity was maximum at $\mathrm{pH}$ range of 6.0 to 6.5 using two bacterial strains, Bacillus licheniformis BF2 isolated from the foregut of bata fish (Labeo bata) and Bacillus subtilis $\mathrm{BH} 4$ isolated from the hindgut of bata fish (Labeo bata) (Ray et al.2012b). Increasing $\mathrm{pH}$ beyond optimum level could interfere with amino acid composition of the enzyme leading to the significant decrease of the enzyme activity (Esakkiraj et al. 2007). Optimum protease production using B. subtilis and the highest protease activity were reached at $\mathrm{pH} 10.0$ (Pant et al. 2015). Sethi et al. (2013) reported optimum pH required for producing cellulase using several soil bacterial species. In a detailed investigation, Fagade and Bamigboye (2012) also optimized culture media parameters for cellulase production. The results of their study showed that $\mathrm{pH} 7.0$ was optimum for bacterial strains Pseudomonas putida, Bacillus subtilis and Bacillus licheniformis I, however, $\mathrm{pH} 5.5$ was recorded to be the best for cellulase production using bacterial isolate Bacillus licheniformis II.

Incubation period is an important parameter for enzyme production by the microorganisms. Some microorganisms produce maximally in their exponential growth phase, while other

Table 3 Effect of fermentation period on enzymes production

\begin{tabular}{|c|c|c|c|c|}
\hline \multirow{2}{*}{$\begin{array}{c}\text { Fermentation } \\
\text { period } \\
\text { (hours) }\end{array}$} & \multicolumn{2}{|c|}{ Specific activity of protease $\left(\mathrm{U}^{1}\right)$} & \multicolumn{2}{|c|}{ Specific activity of cellulase $\left(\mathrm{U}^{2}\right)$} \\
\hline & ATH3 & $\mathrm{CBH} 7$ & ATH3 & $\mathrm{CBH} 7$ \\
\hline 24 & $1.98 \pm 0.121^{\mathrm{d}}$ & $0.36 \pm 0.062^{\mathrm{d}}$ & $3.87 \pm 0.326^{\mathrm{d}}$ & $2.14 \pm 0.141^{\mathrm{e}}$ \\
\hline 48 & $2.72 \pm 0.141^{b}$ & $0.88 \pm 0.141^{\mathrm{c}}$ & $5.23 \pm 0.248^{c}$ & $2.99 \pm 0.283^{d}$ \\
\hline 72 & $3.06 \pm 0.206^{\mathrm{b}}$ & $1.57 \pm 0.262^{\mathrm{b}}$ & $8.53 \pm 0.655^{\mathrm{a}}$ & $4.58 \pm 0.643^{c}$ \\
\hline 96 & $3.95 \pm 0.206^{\mathrm{a}}$ & $2.32 \pm 0.113^{\mathrm{a}}$ & $8.07 \pm 0.370^{\mathrm{a}}$ & $6.42 \pm 0.471^{\mathrm{a}}$ \\
\hline 120 & $2.32 \pm 0.225^{c}$ & $1.61 \pm 0.347^{\mathrm{b}}$ & $6.29 \pm 0.266^{b}$ & $5.47 \pm 0.481^{b}$ \\
\hline
\end{tabular}

Note: Data are presented as mean \pm SEM. $\mathrm{n}=3$ replications.

Numbers followed by the same letter did not differ significantly at $p<0.05$.

$\mathrm{U}^{1}=\mu \mathrm{g}$ of tyrosine liberated $/ \mathrm{mg}$ protein/minute.

$\mathrm{U}^{2}=\mu \mathrm{g}$ of glucose liberated $/ \mathrm{mg}$ protein $/$ minute. 
microorganisms exhibited maximum production in their stationary growth phase. Bacterial strains, C. alkanolyticum ATH3 and B. licheniformis $\mathrm{CBH} 7$ exhibited the highest protease activity $(3.95 \pm 0.206$ $\mathrm{U}$ and $2.32 \pm 0.113 \mathrm{U}$, respectively) at 96 hours fermentation period (Table 3 ).

Cellulase production exhibited by $C$. alk.anolyticum ATH3 was maximum at 72 hours of incubation period $(8.53 \pm 0.655 \mathrm{U})$. B. licheniformis $\mathrm{CBH} 7$ exhibited maximum cellulase production at 96 hours $(6.42 \pm 0.471 \mathrm{U})$ (Table 3). Singh and Kaur (2012) optimized the culture condition for cellulase production using Bacillus sphaericus JS1 and recorded maximum cellulase production at 48 hours of incubation period. In the year 2013, Suganthi et al. (2013) also optimized the culture condition of $B$. licheniformis and stated that the maximum protease production occurred at 24 hours of incubation period. The optimization of incubation period is crucial for obtaining maximum product and thus, several investigations have been conducted in this direction (Shafee et al. 2005; Ray et al. 2007; Sethi et al. 2013). Bacterial growth physiology (lag, log, stationary and decline phase) in liquid medium depends on incubation period. In general, maximum enzymes are produced during the log phase and then decreased rapidly due to interference of secondary metabolites.

Inoculum size is a crucial factor in fermentation process, as the duration of bacterial lag phase is highly dependent on inoculums quantity. The culture used to inoculate the fermentation medium must be in a healthy condition. In this present experiment, a wide range of inoculums size (1 to 5\%) was used to get the maximum yield. Protease production by $C$. alkanolyticum $\mathrm{ATH} 3$ and B. licheniformis $\mathrm{CBH} 7$ was the highest when the inoculum size was $2 \%$ $(4.04 \pm 0.132 \mathrm{U})$ and $3 \%(2.39 \pm 0.243 \mathrm{U})$, respectively (Table 4).

Cellulase activities exhibited by $C$. alkanolyticum ATH3 (8.58 $\pm 0.340 \mathrm{U})$ and B. licheniformis $\mathrm{CBH} 7$ $(6.51 \pm 0.473 \mathrm{U})$ were found to be the highest at $3 \%$ inoculum size (Table 4$)$. Inoculum quantity normally used is between $3 \%$ and $10 \%$ of the medium volume (Lincoln 1960; Meyrath \& Suchanek 1972; Hunt \& Stieber 1986). Lincoln (1960) stressed that bacterial inocula should be transferred in the logarithmic growth phase when the cells were still metabolically active. Shafee $\mathrm{et}$ al. (2005), however, reported that $4 \%$ is the optimum inoculum size for protease production in B. cereus strain 146. Similarly, Goyal et al. (2014) obtained the highest cellulase activity produced by Bacillus sp. at $1 \%$ inoculum size using rice straw as substrate. In recent years, the effects of inoculum sizes on protease and cellulase production have been investigated and published by several researchers (Suganthi et al. 2013; Agarwal et al. 2014; Lugani et al.2015).

Temperature plays a critical role in maintaining normal body physiology in all living organisms, including bacteria. Maximum protease yield by $B$. licheniformis $\mathrm{CBH} 7$ was observed when incubation temperature was $40{ }^{\circ} \mathrm{C}(2.47 \pm 0.461 \mathrm{U})$, while $C$. alkanolyticum $\mathrm{ATH} 3$ exhibited the highest protease production at $45^{\circ} \mathrm{C}(4.18 \pm 0.57 \mathrm{U})$ (Table 5).

Table 4 Effect of inoculum size on enzymes production

\begin{tabular}{|c|c|c|c|c|}
\hline \multirow{2}{*}{$\begin{array}{l}\text { Inoculum size } \\
\qquad(\%)\end{array}$} & \multicolumn{2}{|c|}{ Specific activity of protease $\left(\mathrm{U}^{1}\right)$} & \multicolumn{2}{|c|}{ Specific activity of cellulase $\left(\mathrm{U}^{2}\right)$} \\
\hline & ATH3 & $\mathrm{CBH} 7$ & ATH3 & $\mathrm{CBH} 7$ \\
\hline 1 & $2.98 \pm 0.208^{\mathrm{b}}$ & $0.82 \pm 0.06^{c}$ & $6.23 \pm 0.317^{c}$ & $3.58 \pm 0.26^{c}$ \\
\hline 2 & $4.04 \pm 0.132^{\mathrm{a}}$ & $1.43 \pm 0.2^{\mathrm{b}}$ & $7.16 \pm 0.416^{\mathrm{b}}$ & $5.63 \pm 0.70^{\mathrm{b}}$ \\
\hline 3 & $3.10 \pm 0.384^{b}$ & $2.39 \pm 0.243^{\mathrm{a}}$ & $8.58 \pm 0.340^{\mathrm{a}}$ & $6.51 \pm 0.473^{a}$ \\
\hline 4 & $0.87 \pm 0.079^{c}$ & $0.98 \pm 0.124^{c}$ & $3.23 \pm 0.245^{\mathrm{d}}$ & $3.42 \pm 0.205^{c}$ \\
\hline 5 & $0.21 \pm 0.069^{\mathrm{d}}$ & $0.27 \pm 0.036^{\mathrm{d}}$ & $2.01 \pm 0.13^{\mathrm{e}}$ & $2.22 \pm 0.246^{\mathrm{d}}$ \\
\hline
\end{tabular}

Note: Data are presented as mean \pm SEM. $n=3$ replications.

Numbers followed by the same letter did not differ significantly at $\mathrm{p}<0.05$.

$\mathrm{U}^{1}=\mu \mathrm{g}$ of tyrosine liberated $/ \mathrm{mg}$ protein/minute.

$\mathrm{U}^{2}=\mu \mathrm{g}$ of glucose liberated $/ \mathrm{mg}$ protein $/$ minute. 
Table 5 Effect of different temperature on enzymes activity

\begin{tabular}{|c|c|c|c|c|}
\hline \multirow{2}{*}{$\begin{array}{c}\text { Different } \\
\text { temperature } \\
\left({ }^{\circ} \mathrm{C}\right)\end{array}$} & \multicolumn{2}{|c|}{ Specific activity of protease $\left(\mathrm{U}^{1}\right)$} & \multicolumn{2}{|c|}{ Specific activity of cellulase $\left(\mathrm{U}^{2}\right)$} \\
\hline & ATH3 & $\mathrm{CBH} 7$ & ATH3 & $\mathrm{CBH} 7$ \\
\hline 20 & $0.73 \pm 0.081^{\mathrm{e}}$ & $0.46 \pm 0.043^{c}$ & $2.87 \pm 0.182^{\mathrm{d}}$ & $2.72 \pm 0.25^{\mathrm{d}}$ \\
\hline 30 & $1.45 \pm 0.105^{\mathrm{d}}$ & $0.79 \pm 0.19 c$ & $5.13 \pm 0.228^{c}$ & $3.79 \pm 0.255^{c}$ \\
\hline 35 & $2.23 \pm 0.246^{c}$ & $1.51 \pm 0.173^{b}$ & $7.18 \pm 0.55^{\mathrm{b}}$ & $4.92 \pm 0.56^{\mathrm{b}}$ \\
\hline 40 & $3.19 \pm 0.42^{b}$ & $2.47 \pm 0.158^{a}$ & $8.66 \pm 0.762^{a}$ & $6.63 \pm 0.34^{a}$ \\
\hline 45 & $4.18 \pm 0.42^{\mathrm{a}}$ & $0.88 \pm 0.131^{c}$ & $5.03 \pm 0232^{c}$ & $4.42 \pm 0.482^{b}$ \\
\hline 50 & $1.99 \pm 0.19 \mathrm{c}$ & $0.45 \pm 0.072^{c}$ & $1.89 \pm 0.122^{\mathrm{e}}$ & $2.34 \pm 0.381^{\mathrm{d}}$ \\
\hline
\end{tabular}

\footnotetext{
Note: Data are presented as mean \pm SEM. $n=3$ replications.

Numbers followed by the same letter did not differ significantly at $p<0.05$.

$\mathrm{U}^{1}=\mu \mathrm{g}$ of tyrosine liberated $/ \mathrm{mg}$ protein/minute.

$\mathrm{U}^{2}=\mu \mathrm{g}$ of glucose liberated $/ \mathrm{mg}$ protein $/$ minute.
}

On the other hand, the highest cellulase activity exhibited by these strains was observed at $40{ }^{\circ} \mathrm{C}$ (8.66 $\pm 0.762 \mathrm{U}$ for C. alkanolyticum ATH3 and $6.63 \pm 0.34 \mathrm{U}$ for B. licheniformis CBH7) (Table 5). In this direction, Ray et al. (2007) observed and stated that $40{ }^{\circ} \mathrm{C}$ is the most effective temperature for cellulase production using $B$. subtilis CY5 and B. circulans TP3. Transport of enzymes to extracellular medium is lower at low temperature compared to that at high temperature (Rajoka 2004). However, at higher temperature, the high maintenance of energy requirement for cellular growth is needed due to thermal denaturation of enzymes of the metabolic pathway (Aiba et al. 1973), resulting in maximum production. Recently, Pant et al. (2015) reported 44 ${ }^{\circ} \mathrm{C}$ as the most effective temperature for protease production using Bacillus subtilis. On the other hand, Sethi et al. (2013) optimized the cellulase production using different soil bacterial strains and reported that $40{ }^{\circ} \mathrm{C}$ as the optimum temperature. Rasul et al. (2015) also isolated different bacterial strains from soil and sugar industries and optimized their cellulase production. Microorganisms grow slowly at a temperature below or above the normal growth temperature due to a reduced rate of cellular production (Ray et al. 2007). Therefore, it is important to maintain ambient temperature to obtain maximum production.

Effect of various carbon sources on protease and cellulase production were presented in Figure $1 \mathrm{a}$ and $1 \mathrm{~b}$, respectively.
Among seven carbon sources, fructose and sucrose were detected to be the most suitable carbon sources for protease production using $C$. alkanolyticum ATH3 $(4.25 \pm 0.52 \mathrm{U})$ and $B$. licheniformis $\mathrm{CBH} 7(2.53 \pm 0.28 \mathrm{U})$. On the other hand, glucose was recorded to be more effective for cellulase production using $C$. alkanolyticum ATH3 (8.71 $\pm 0.78 \mathrm{U})$ and B. licheniformis $\mathrm{CBH} 7$ $(6.66 \pm 0.61 \mathrm{U})$. It is well established that carbohydrates induce most of the cellulolytic enzymes in bacteria and fungi (Morikawa et al. 1995). Rajoka and Malik (1997) used cellulose, cellulosic residues, xylan, cellobiose and CMC as carbon sources for the enhanced production of cellulases using Cellulomonas strain. Juhász et al. (2005) reported that high cellulolytic activity could be enhanced using steam-pretreated corn stover as carbon source. Carbon sources are very important for bacterial protease and cellulase production (Sethi et al. 2013; Suganthi et al. 2013; Pant etal.2015).

Nitrogen sources are the building block of amino acids and considered to be the most important parameter in enzyme production. Among various inorganic and organic nitrogen sources, tryptone was detected to be the most important nitrogen source in both protease $(4.33 \pm 0.388 \mathrm{U}$ and $2.64 \pm 0.17 \mathrm{U})$ and cellulase $(8.77 \pm 0.66 \mathrm{U}$ and $6.72 \pm 0.38 \mathrm{U})$ production using C. alkanolyticum ATH3 and B. licheniformis $\mathrm{CBH} 7$ (Fig. 2a \& 2b).

Recently, Lugani et al. (2015) tested the effect of different nitrogen sources (peptone, yeast 

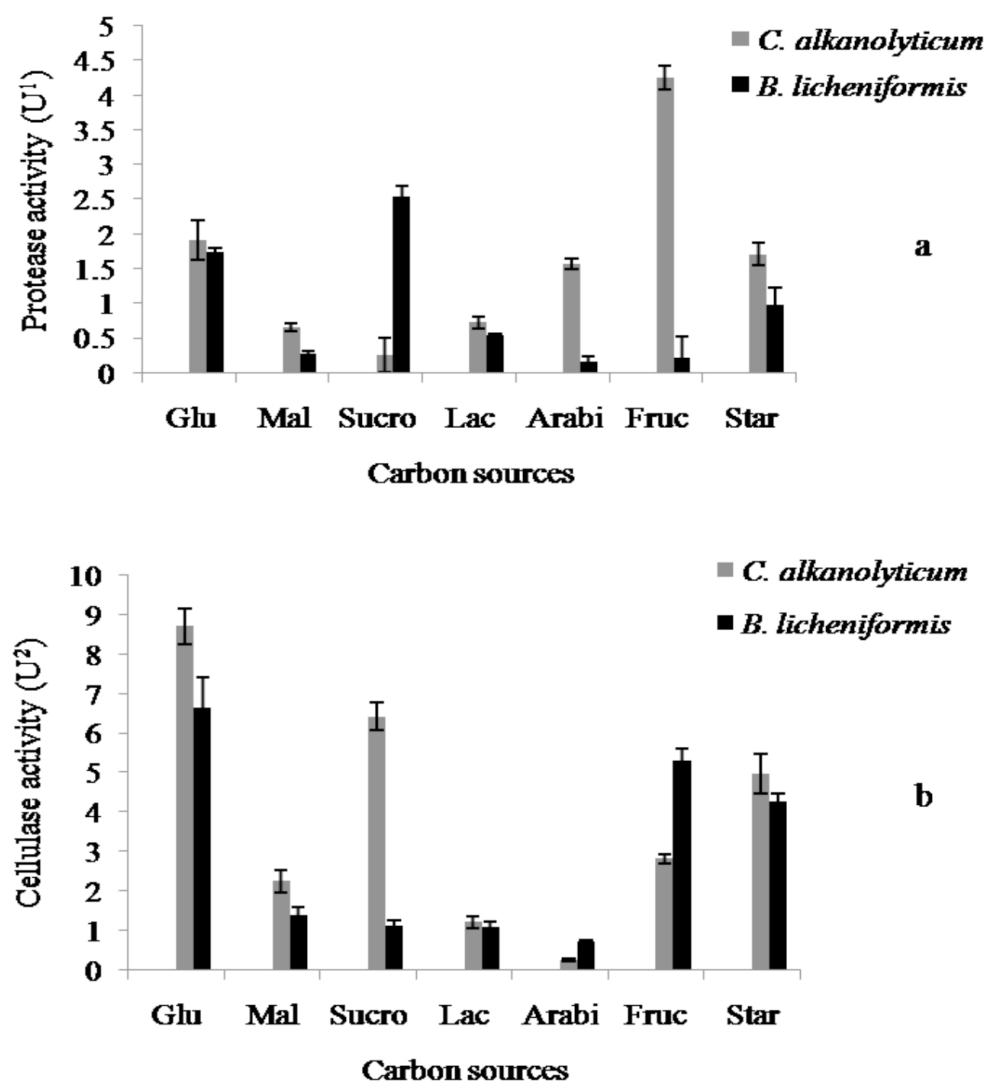

Figure 1 Effect of different carbon sources on enzyme production

(Note: $\mathrm{Glu}=$ glucose $; \mathrm{Mal}=$ maltose $;$ Sucro $=$ sucrose $; \mathrm{Lac}=$ lactose $;$ Arabi $=$ arabinose $;$ Fruc $=$ fructose $;$ Star $=$ starch. Data are presented as mean \pm SEM. $a=$ protease activity; $\mathrm{b}=$ cellulase activity. $\mathrm{U}^{1}=\mu \mathrm{g}$ of tyrosine liberated $/ \mathrm{mg}$ protein $/ \mathrm{minute} ; \mathrm{U}^{2}=$ $\mu \mathrm{g}$ of glucose liberated/mg protein/minute)
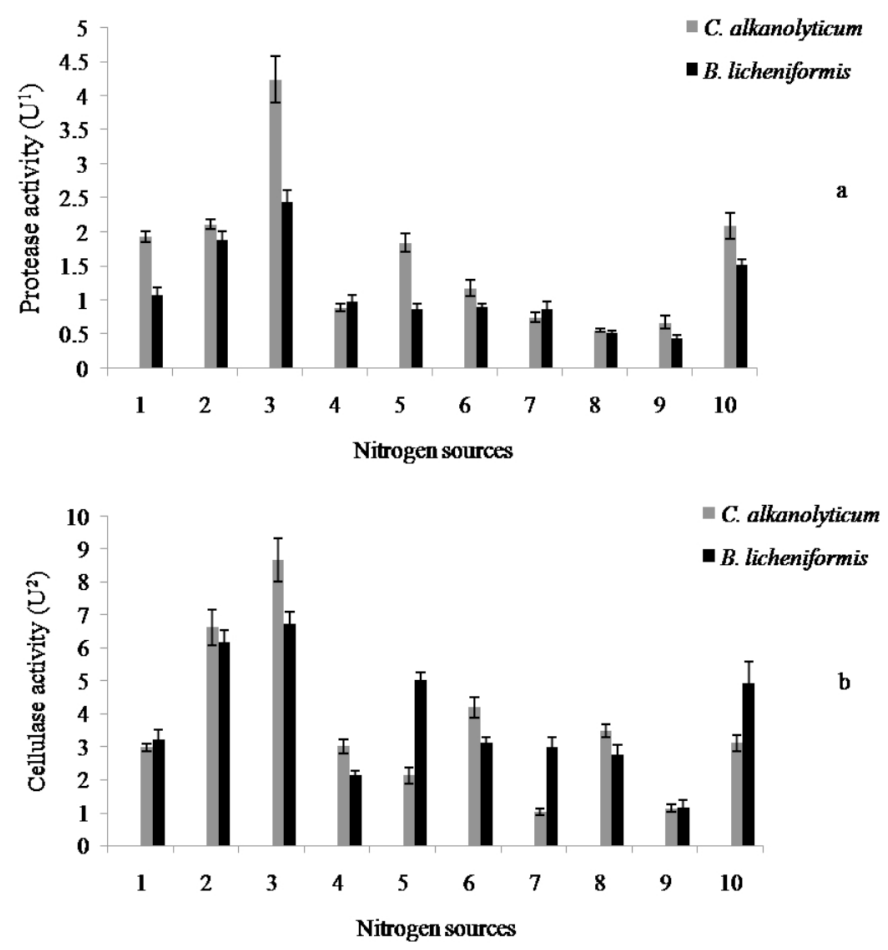

Figure 2 Effect of nitrogen sources on protease and cellulase production

(Note: $1=$ arginine; $2=$ beef; $3=$ tryptone; $4=$ aspergine; $5=$ tyrosine; $6=\mathrm{NH}_{4} \mathrm{Cl} ; 7=\mathrm{NaNO}_{3} 8=\left(\mathrm{NH}_{4}\right)_{2} \mathrm{SO}_{4} ; 9=\mathrm{KNO}_{3}$ $10=$ gelatin. $\mathrm{a}=$ protease activity; $\mathrm{b}=$ cellulase activity. Data are presented as mean \pm SEM. $\mathrm{U}^{1}=\mu \mathrm{g}$ of tyrosine liberated $/ \mathrm{mg}$ protein $/$ minute; $\mathrm{U}^{2}=\mu \mathrm{g}$ of glucose liberated $/ \mathrm{mg}$ protein $/$ minute) 
extract, ammonium sulphate, ammonium chloride and ammonium nitrate) on cellulase production from bacterial source. Results of their investigation reported peptone as the effective nitrogen source in culture medium of Bacillus sp. Y3. In this direction, Ray et al. (2007) stated that organic nitrogen sources exert better result compared to inorganic nitrogen sources in cellulase production using Bacillus subtilis CY 5 and B. circulans TP3. In recent years, the effects of nitrogen sources on bacterial protease production have also been reported by several researchers (Ray et al. 2012b; Suganthi et al. 2013; Nisha \& Divakaran 2014; Pant et al. 2015). In the present study, inorganic nitrogen sources and other amino acids such as $\mathrm{L}$-aspergine and tyrosine were the poor nitrogen sources for cellulase production. On the contrary, Spiridonov and Wilson (1998) found that $\mathrm{NH}_{4}$ compounds are the most favorable nitrogen sources for protein and cellulase synthesis.

Bacterial flora existing in digestive tract represents a very important and diversified enzymatic potential (Ray et al. 2012a; Banerjee et al. 2013; Banerjee \& Ray 2016). Extracellular enzymes production using bacterial flora not only helps in digestion, but also has great application in different industries (Saha et al. 2006; Roy et al. 2009; Ringø et al. 2012; Banerjee \& Ray 2016). Among several enzymes, microbial protease and cellulase have high demand in different biotechnological industries such as food, leather, beverage and detergent (Banerjee et al. 2015b). Production of these different types of extracellular enzymes largely depends on medium compositions and different physical factors (Ray et al. 2012b). Medium optimization is the most important step to enhance the production in laboratory experiments and in fermentation industries. Until now, reports on optimization of enzymes produced by gut bacteria are scanty, and thus, extensive research should be conducted to fulfill the demand.

\section{CONCLUSIONS}

This study emphasized on production maximization of bacterial protease and cellulase due to their important contribution in several biotechnological industries. Bacterial strains Corynebacterium alkanolyticum ATH3 and Bacillus licheniformis $\mathrm{CBH} 7$ as active producer of extracellular protease and cellulase, might be useful in different industries like bakery, dairy, meat, like textile, food, laundry, paper, biofuel and brewing sectors.

\section{ACKNOWLEDGEMENTS}

We are very much thankful to University Grants Commission (UGC), New Delhi, for financial support. We are also grateful to Department of Zoology, Visva-Bharati University, India, for providing such vast support.

\section{REFERENCES}

Agarwal T, Saxena MK, Chandrawat MPS. 2014. Production and optimization of cellulase enzyme by Pseudomonas aeruginosa MTCC 4643 using sawdust as a substrate. Int J Sci Res 4:1-3.

Aiba S, Humphrey AE, Millis NF. 1973. Biochemical engineering. Second Edition. New York (US): Academic Press. p. 92-127.

Banerjee G, Ray AK, Askarian F, Ringø E. 2013. Characterization and identification of enzymeproducing autochthonous bacteria from the gastrointestinal tract of two Indian air-breathing fish. Benef Microbes 4:277-84.

Banerjee G, Dan SK, Nandi A, Ghosh P, Ray AK. 2015a. Autochthonous gut bacteria in two Indian airbreathing fish, climbing perch (Anabas testudineus) and walking catfish (Clarias batrachus): Mode of association, Identification and enzyme producing ability. Pol J Microbiol 64:371-78.

Banerjee G, Mukherjee S, Bhattacharya S, Ray AK. 2015b. Purification and characterization of extracellular protease and amylase produced by the bacterial strain, Corynebacterium alkanolyticum ATH3 isolated from Fish gut. Arab J Sci Eng 41:9-16.

Banerjee G, Ray AK. 2013. Characterization and identification of protease and amylase-producing bacteria isolated from gastrointestinal of climbing perch, Anabas testudineus. Decan Curr Sci 9:150-59.

Banerjee G, Ray AK. 2016. Bacterial symbiosis in the fish gut and its role in health and metabolism. Symbiosis 72:1-11.

Barr BK, Hsieh Y-L, Ganem B, Wilson DB. 1996. Identification of two functionally different classes of exocellulases. Biochem 35:586-92.

Beg KB, Gupta R. 2003. Purification and characterization of an oxidation-stable, thiol-dependent serine alkaline protease from Bacillus mojavensis. Enzyme Microb Technol 32:294-304. 
Denison DA, Kohen RD. 1977. Cellulase activity of Poronia oedipus. Mycologia 69:592-601.

Duncan DB. 1955. Multiple range and multiple F-teat. Biometrics 11:1-42.

Esakkiraj PG, Immanuel S, Sowmya M, Iyapparaj P, Palavesam A. 2007. Evaluations of protease producing ability of fish gut isolate Bacillus cereus for aqua feed. Food Bioprocess Technol Springer Sci 2:383-90.

Fagade OE, Bamigboye OO. 2012. Effect of cultural conditions on the cellulase activity of bacterial species isolated from degrading corn cob. Arch Appl Sci Res 4:2540-5.

Goodenough S, Goodenough P. 1993. Who needs cellulase? J Biol Educ 27:97-102.

Goyal V, Mittal A, Bhuwal AK, Singh G, Yadav A, Aggarwal NK. 2014. Parametric optimization of cultural conditions for carboxymethyl cellulase production using pretreated rice straw by Bacillus sp. 313SI under stationary and shaking conditions. Biotechnol Res Int 2014:651839. DOI:10.1155/2014/651839.

Gupta R, Beeg QK, Loranz P. 2002. Bacterial alkaline proteases: molecular approaches and industrial applications. Appl Microbiol Biotechnol 59:15-32.

He S, Liang X-F, Li L, Sun J, Wen Z-Y, Cheng X-Y,... Yuan X-C. 2015. Transcriptome analysis of food habit transition from carnivory to herbivory in a typical vertebrate herbivore, grass carp Ctenopharyngodon idella. BMC Genomics 16:15. DOI: 10.1186/s12864-015-1217-x.

Hunt GR, Stieber RW. 1986. Inoculum development. In: Manual of industrial microbiology and biotechnology. Demain AL, Solomon NA, editors. Washington DC (US): American Society of Microbiology.

Juhász T, Szengyel Z, Reczey K, Siika-Aho M, Viikari L. 2005. Characterization of cellulases and hemicellulases produced by Trichoderma reesei on various carbon sources. Process Biochem 40:351925 .

Lincoln RE. 1960. Control of stock culture preservation and inoculum build-up in bacterial fermentations. J Biochem Microbiol Technol 2:481-500.

Lowry OH, Rosebrough NJ, Farr AL, Randall RJ. 1951. Protein measurement with the folin phenol reagent. J Biol Chem 193:265-275.

Lugani Y, Singla R, Sooch BS. 2015. Optimization of cellulase production by newly isolated Bacillus sp. Y3. J Bioprocess Biotech 5:264. DOI 10.4172/21559821.1000264.

Meyrath J, Suchanek G. 1972. Inoculation techniques effects due to quality and quantity of inoculum. In: Methods in Microbiology. Norris JR, Ribbons DW, editors. London (UK): Academic Press. p. 159-209.
Morikawa Y, Ohashi T, Mantani O, Okada H. 1995. Cellulase induction by lactose in Trichoderma reesei PC-3-7. Appl Microbiol Biotechnol 44:106-11.

Nisha NS, Divakaran J. 2014. Optimization parameters for alkaline protease production by bacterial isolates from different coastal regions of Tamil Nadu, India. Int J Curr Microbiol Appl Sci 3:500-5.

Pant G, Prakash A, Pavani JVP, Bera S, Deviram GVNS, Kumar A, ... Prasuna RG. 2015. Production, optimization and partial purification of protease from Bacillus subtilis. J Taibah Univ Sci 9:50-5.

Pastor MD, Lorda GS, Balatti A. 2001. Protease ostentation using Bacillus subtillis 3411 and amaranth seed meal medium at different aeration rates. Braz J Microbiol 32:6-9.

Rajoka MI, Malik KA. 1997. Cellulase production by Cellulomonas biazotea cultured in media containing different cellulosic substrates. Bioresour Technol 59:21-7.

Rajoka MI. 2004. Influence of various fermentation variables on exo-glucanase production in Cellulomonas flavigena. Electron J Biotechnol $7: 256-63$.

Rao BM, Tanksale MA, Ghatge SM, Deshpande VV. 1998. Molecular and biotechnological aspects of microbial proteases: Microbiol Mol Biol Rev 62:597635.

Rasul F, Afroz A, Rashid U, Mehmood S, Sughra K, Zeeshan N. 2015. Screening and characterization of cellulase producing bacteria from soil and waste (molasses) sugar industry. Int J Biosci 6:230-8.

Ray AK, Bairagi A, Sarkar GK, Sen SK. 2007. Optimization of fermentation conditions for cellulase production by Bacillus subtilis CY5 and Bacillus circulans TP3 isolated from fish gut. Acta Ichthyolo et Piscat $37: 47-53$

Ray AK, Ghosh K, Ringø E. 2012a. Enzyme-producing bacteria isolated from fish gut. A review. Aquacult Nutr 18:465-92.

Ray AK, Mondal S, Roy T. 2012b. Optimization of culture conditions for production of protease by two bacterial strains, Bacillus licheniformis BF2 and Bacillus subtilis $\mathrm{BH} 4$ isolated from the digestive tract of bata, Labeo bata (Hamilton). Proc Zool Soc 65: 33-9.

Ringø E, Zhou E, Olsen RE, Song SK. 2012. Use of chitin and krill in aquaculture - the effect on gut microbiota and the immune system: a review. Aquacult Nutr 18:117-31.

Roy T, Mondal S, Ray SK. 2009. Phytase producing bacteria in digestive tract of some fresh water fish. Aquacult Res 40:344-53.

Saddler JN 1993. Bioconversion of forest and agricultural plant residues. Biotechnol Agricul 9:349. 
Saha S, Roy RN, Sen SK, Ray AK. 2006. Characterization of cellulase-producing bacteria from the digestive tract of tilapia, Oreochromis mossambica $(\mathrm{P})$ and grass carp, Ctenopharyngodon idella (V). Aquacult Res 37:380-88.

Sethi S, Datta A, Gupta BL, Gupta S. 2013. Optimization of cellulase production from bacteria isolated from soil. ISRN Biotechnol 2013:985685. DOI: 10.5402/2013/985685.

Shafee N, Norariatis AS, Zaliha ARN, Basri M. 2005. Optimization of environmental and nutritional conditions for the production of alkaline protease by a newly isolated bacterium Bacillus cereus strain 146. J Appl Sci Res 1:1-8.

Singh J, Kaur P. 2012. Optimization of process parameters for cellulase production from Bacillus sp. Js14 in solid substrate fermentation using response surface methodology. Braz Arch Biol Tehcnol 55:505-512.
Spiridonov NA, Wilson DB. 1998. Regulation of biosynthesis of individual cellulases in Thermomonospora fusca. J Bacteriol 180:3529-32.

Suganthi C, Mageswari A, Karthikeyan S, Anbalagan M, Sivakumar A, Gothandam KM. 2013. Screening and optimization of protease production from a halotolerant Bacillus licheniformis isolated from saltern sediment. J genet Eng Biotechnol 11:47-52.

Vijayaraghavan P, Lazarus S, Vincent SGP. 2014. De-hairing protease production by an isolated Bacillus cereus strain AT under solid-state fermentation using cow dung: biosynthesis and properties. Saudi J Biol Sci 21:27-34.

Walter HE. 1984. Methods of enzymatic analysis. Weinheim (DE): Verlag Chemie. p. 238. 